\title{
вмJ Global Health Austerity, resilience and the management of actors in public hospitals: a qualitative study from South Africa
}

\author{
Thanduxolo Fana (D) , Jane Goudge (D) ${ }^{2}$
}

To cite: Fana T, Goudge J. Austerity, resilience and the management of actors in public hospitals: a qualitative study from South Africa. BMJ Global Health 2021;6:e004157. doi:10.1136/ bmjgh-2020-004157

Handling editor Stephanie M Topp

- Additional material is published online only. To view please visit the journal online (http://dx.doi.org/10.1136/ bmjgh-2020-004157).

Received 9 0ctober 2020 Revised 5 February 2021 Accepted 10 February 2021

Check for updates

(C) Author(s) (or their employer(s)) 2021. Re-use permitted under CC BY-NC. No commercial re-use. See rights and permissions. Published by BMJ.

${ }^{1}$ Faculty of Health Sciences, School of Public Health, Centre for Health Policy, University of the Witwatersrand, Johannesburg, Gauteng, South Africa

${ }^{2}$ Centre for Health Policy, University of the Witwatersrand School of Public Health, Johannesburg, Gauteng, South Africa

Correspondence to

Thanduxolo Fana;

unamthanduxolo@gmail.com

\section{ABSTRACT}

Background Global economic recession coupled with internal inefficiencies and corruption has led to a period of austerity in the South African healthcare system. This paper examines the strategies used by management in response to austerity in the three public hospitals and their effect on organisational functioning. Methods We used a comparative qualitative case study approach, collecting data using a combination of in-depth interviews with managers, and focus group discussion and interviews with shop stewards and staff. Results Austerity, imposed by the introduction of a provincial cost containment committee, has led to a reduction in staff, benefits, shortages of equipment and delayed procurement and recruitment processes. Managers in the first hospital maintained training on labour relations for staff and managers, they jointly planned how to cope with reduced staff and initiated a new forum for HR and finance staff. These strategies improved the way actors engaged, enabling them to resolve problems. Good communication ensured that staff understood what was within the hospitals control and what was not. A second hospital relied on absorptive strategies, such as asking staff to do more with less. The result was resistance, and greater use of sick leave. Some staff gave their own money to help feed patients but were angry at management for putting them in this difficult position. Leadership in the third hospital did not manage actors well either; help from the Government's Expanded Public Works Programme was rejected by the unions, managers did not attend meetings as they felt their contributions were not listened to. Poor communication meant that the managers and staff did not understand what was within the hospital's control and what was not; a misunderstanding led to a physical fight between managers.

Conclusion Organisational resilience in the face of austerity requires leaders to manage different stakeholders well. Hospital managers who promote democratic or participatory leadership and management, open communication, teamwork and trust among all stakeholders will lead better functioning organisations. A special focus should be placed on such practices to develop the resilience of health systems' organisations.
Key questions

What is already known?

- Austerity led to reductions in staff, benefits, shortages of equipment and delayed procurement and recruitment processes.

- Strategies in response to shocks have been categorised as absorptive, adaptive and transformative.

- There is limited knowledge on the types of strategies and the effect of leadership and management style on employee responses and organisational functioning.

What are the new findings?

- Managers who relied only on absorptive strategies (asking staff to do more with less, including operating outside of the clinical scope of practice) weakened their institutions. Staff resisted such strategies and made greater use of sick leave. With poor communication, tensions rose leading to conflict between and within departments, worsening communication and so reducing the resilience of the organisations.

- Managers who purposively intensified their communication with staff led better functioning, and more resilient organisations. Staff understood what was within the hospitals control and what was not. They jointly planned how to cope with reduced staff, and initiated new fora for engagement, that aided in the development of local solutions.

\section{What do the new findings imply?}

- Organisational resilience depends on the capacity to manage actors, networks and institutions and shape the implicit and explicit rules that shape power, relationships and actions.

- Managers who promote democratic or participatory leadership and management, open communication, teamwork and trust among all stakeholders will lead better functioning organisations.

- Special focus should be placed on developing and promoting such skills and practices.

\section{INTRODUCTION}

In the wake of the 2008 global financial crisis, negative or slow economic growth 
in low-income and middle-income countries (LMICs) resulted in tax revenue shortfalls, exacerbated by diminishing foreign financial assistance. Health spending as a percentage of gross domestic product (GDP) declined on average by $3 \%$ in 128 LMIC's from 2008 to $2010 .^{1-3}$ Numerous governments instituted austerity programmes to address the increasing deficits and unsustainable debts. ${ }^{4}$ With the current COVID-19 pandemic, the accompanying fiscal stimulus packages and resulting debt, austerity is likely to be a common experience in many settings over the next decade, affecting many health systems.

A significant reduction in available resources is damaging for any organisation, and resilience is important attribute, likely to determine whether everyday work systems and practices are maintained as the organisation adjusts. ${ }^{6}$ Resilience of a health system is its "capacity to absorb, adapt and transform when exposed to a shock such as a pandemic, natural disaster, armed conflict or a financial crisis and still retain the same control over its structure and functions'. ${ }^{7}$ Resilience capacity has been characterised as the: (i) capacity to collect, integrate and analyse different forms of knowledge and information; (ii) ability to anticipate and cope with uncertainties and surprises; (iii) capacity to manage interdependence of different parts of an organisation. ${ }^{7}$ Building such capacity requires collaboration; working effectively together. Yet, do managers and staff work together to develop collective strategies in the face of austerity, or do tensions surface, as managers compete for scarce resources, worsening organisational performance? What strategies enable an organisation to facilitate cooperation and so develop resilience and weather the storm? These are critical questions that relate to management and governance of health system.

South Africa was able to withstand the initial effect of the 2008 global financial crisis due to a counter-cyclical fiscal stance. However, by 2013, economic growth slowed and there was a decline in real terms health budgets from 2013 to $2020 .^{5}$ Numerous cost-saving exercises have been implemented over the past 5 years, included the freezing of posts, prioritisation of core items over the less essential and reducing infrastructure spending. ${ }^{8}$ In this paper, we compare the responses to austerity in the three hospitals in a poor rural province in South Africa, contrasting absorptive strategies that expect more effort from fewer staff, adaptive strategies that draw resources from elsewhere and transformative strategies that improve the way actors engage with each other, so enable resilience.

\section{Background}

Although South Africa spends almost $8.8 \%$ of the national income on healthcare, poverty, unemployment, and high levels of TB, HIV/AIDS and non-communicable diseases, have led to limited improvements in health outcomes. ${ }^{9}$ Reports by the media and communities have shown that services in public healthcare facilities are failing to meet basic standards of care and patient expectations. ${ }^{58}$ The healthcare system is facing challenges of insufficiently skilled management and staff shortages. ${ }^{910}$ Coupled with the broader economic environment described above, higher-than-inflation increases in wages and the costs of medical products, proliferation of medical negligence litigations, ${ }^{9}$ as well as internal inefficiencies, corruption, wasteful expenditure and irrational decision-making, have compounded these problems and led to the need for a period of austerity. ${ }^{11}$

Resilience is generally understood as the capacity of a system to recover from a shock or disturbance; ${ }^{12}{ }^{13}$ the capacity to make positive adjustments under challenging circumstances such that the organisation emerges from those conditions strengthened and more resourceful. ${ }^{13}$ While we have drawn on Gilson's terminology to describe strategies in response to shocks or disturbances (absorptive, adaptive and transformation), ${ }^{14}$ we have defined the strategies, based on the type of strategy or action used by management. Some strategies are absorptive, using existing resources (eg, staff doing extra work, taking on additional roles outside of their job description or scope of practice), which can have negative consequences for the individual. Some strategies are adaptive, involving reprioritisation of work or drawing in resources from another source or location (eg, moving staff from one team to another, outsourcing services rather than employing staff directly); these may have negative consequences elsewhere in the organisation or health system. Other strategies are transformative in that they change the way the actors engage with each other (eg, involving staff in planning how to cope with austerity, providing training for managers and staff on labour relations to ensure tensions generated by austerity are resolved appropriately).

\section{METHODS}

\section{Study design}

We used qualitative methods with a case study design to gain an understanding of the perspective of those working in the public hospitals, and of the context, and the challenges they faced.

\section{Study setting and sites}

This study was conducted in three public hospitals in a large rural and remote province in South Africa, with thigh levels of unemployment and poverty. A combination of purposive and convenient sampling strategies was used to select three facilities. First author (TF) had worked for several years in the province, and knew two of the hospitals well, and so was able to gain access to employee for interviews; the third had a reputation for good performance, and so was chosen in order to identify what worked.

The three hospitals are run and funded by government. There is a chief executive officer (CEO), and clinical, nursing services and corporate service managers, as the top tier of management. The CEO reports either to the district and/or the provincial structures. Austerity had 
resulted in implementation of authoritarian management style, and centralisation of financial management negatively affected planning, decision-making and had impaired organisational function at a district level. ${ }^{15}$

Unions are active in all three hospitals, and union shop stewards represent the interests of staff, serving as a communication link between management and staff. They represent staff at disciplinary hearings, union management meetings and hold management accountable to the staff. (In a sister paper, we report specifically management's efforts to cut labour costs, the resulting power struggles between management, unions and staff and effect on the three hospitals.)

Hospital A is a 350-bed specialised provincial tuberculosis referral hospital with 200 staff, and it reports at the district and provincial level. It has experienced instability in leadership with three CEO appointed in the last 5 years and had lost experienced employee in its management team. Hospital B is a 900-bed tertiary hospital with 2000 staff, which reports directly to the province. It is serving a poor community with high levels of unemployment. It had some new management; both the CEO and Director Human Resources were new appointments at the time of the research. Hospital C is a 200-bed general hospital with 600 staff, and an unclear status (as the hospital is categorised as a district hospital at provincial level and a regional hospital at the national level), located in a relatively wealthy community, that used to serve mainly white and coloured community prior to democracy. There is relative continuity in the management, with only the Chief Medical Officer and Finance Manager being employed at the hospital for less than 4 years.

\section{Selection of participant and data collection methods}

We conducted interviews $(n=47)$ with managers, shop stewards and staff, as well as focus group discussions $(\mathrm{n}=12 ; 4$ in each hospital) with staff $(\mathrm{n}=84)$ from April to September 2019 (table 1). The participants were selected through purposive and convenience sampling. Managers and shop stewards were selected purposively because they were responsible for management, supervision of employee and day-to-day decision-making and running of the hospital. Managers interviewed included the CEO, Chief Medical Officer, Clinical Manager, Deputy Director Human Resources, Assistant Director Human Resources Management, Patient Administration, Operations, Finance, Nursing Manager, Area Manager and Operation Managers Nursing in each hospital. Convenience sampling was used to select staff, based on who was available and willing to participate in the study.

Focus group discussions were held with shop stewards, clinical and non-clinical employee. These were supplemented with an in-depth interview with one person from each group to counter the group effect. Participants were asked to introduce themselves (position, education and experience), and to describe their departmental goals, their experiences of working in the hospital, challenges and successes (online supplemental appendix A).
The interviews and focus group discussions were audio recorded and saved in a password-protected computer. Policy on management of public hospitals under National Health Insurance, leave management, recruitment and selection circulars and policies, hospital organograms, minutes of top management and quality assurance meetings were reviewed.

The researchers amended the questions during data collection to take into account knowledge already gained from previous interviews and focus group discussion. The authors discussed the data collected on an ongoing basis and when no new information was emerging and data saturation was reached.

\section{Data analysis}

TF wrote field observation notes after each interview. Two field workers transcribed data, and TF checked the transcriptions for accuracy. TF extracted data into a data extraction sheet for each facility, either as quotes or providing summarised version of events. We (TF and JG) reread the data and identified common and divergent themes across the multiple data sources for each of the three cases, and across the hospitals, identifying differences and similarities. The high-level themes were the implementation of austerity, communication and management style and strategies used to cope with austerity. The authors interrogated the data under each theme, discussing the strength of the evidence, and once we reached an agreement, we identified Gilson's framework, through a literature review, as a useful way to frame the strategies. We then coded the data according to the three strategies (absorptive, adaptive, and transformative) identified in Gilson's framework.

Field notes were used to inform the analysis, but we do not use verbatim quotes from these. In preparation of the article, we continued to visit both the raw and summarised data to confirm descriptions of the content, enrich descriptions of the context, provide clarity and check ideas that emerged.

\section{Positionality}

$\mathrm{TF}$ worked for 10 years as a human resources practitioner at one of the facilities, during which time he interacted with employee from other hospitals in the district and in province. The researcher spent 7 of the 10 years as a National Education Health and Allied Workers Union (NEHAWU) shop steward and the hospital's branch secretary.

In this capacity, the researcher was involved in negotiating with management on behalf of the staff, mediating disputes and grievances and representing staff at disciplinary hearing. TF's previous role may have affected some participant's willingness to participate, as four managers (Labour Relation, Administration, Area Manager Nursing and Social Worker) out of 33 managers across the three hospitals refused to participate. Three groups of staff (food service aids, laundry and cleaners) in one of the hospitals also refused to participate because 
Table 1 Study participants

\begin{tabular}{|c|c|c|c|c|c|c|c|c|c|}
\hline \multirow[b]{2}{*}{ Interviewees } & \multicolumn{3}{|c|}{ Hospital A } & \multicolumn{3}{|c|}{ Hospital B } & \multicolumn{3}{|c|}{ Hospital C } \\
\hline & Race & Gender & $\begin{array}{l}\text { Experience } \\
\text { (years) }\end{array}$ & Race & Gender & $\begin{array}{l}\text { Experience } \\
\text { (years) }\end{array}$ & Race & Gender & $\begin{array}{l}\text { Experience } \\
\text { (years) }\end{array}$ \\
\hline \multirow{11}{*}{$\begin{array}{l}\text { Senior } \\
\text { management } \\
\text { Middle } \\
\text { management }\end{array}$} & B & $\mathrm{F}$ & 35 & $\mathrm{~B}$ & M & 10 & C & $\mathrm{F}$ & 30 \\
\hline & - & - & - & W & $\mathrm{M}$ & 15 & - & - & - \\
\hline & C & M & 10 & $\mathrm{~B}$ & $\mathrm{~F}$ & 25 & W & $\mathrm{F}$ & 35 \\
\hline & - & - & - & B & M & 10 & - & - & - \\
\hline & - & - & - & B & $\mathrm{M}$ & 15 & - & - & - \\
\hline & B & $\mathrm{F}$ & 5 & B & $\mathrm{F}$ & 10 & B & M & 5 \\
\hline & - & - & - & B & $\mathrm{M}$ & 4 & - & - & - \\
\hline & B & M & 7 & - & - & - & W & M & 30 \\
\hline & B & M & 5 & B & M & 10 & B & M & 40 \\
\hline & B & $\mathrm{F}$ & 20 & - & - & - & B & $\mathrm{F}$ & 5 \\
\hline & C & M & 8 & C & M & 15 & $\mathrm{C}$ & M & 10 \\
\hline \multirow[t]{6}{*}{ Shop Stewards } & $\mathrm{B}$ & M & 7 & $\mathrm{~B}$ & $\mathrm{~F}$ & 10 & B & $\mathrm{F}$ & 3 \\
\hline & W & $\mathrm{F}$ & 1 & $\mathrm{C}$ & $\mathrm{M}$ & 2 & C & M & 2 \\
\hline & B & M & 3 & B & $\mathrm{F}$ & 15 & B & $\mathrm{F}$ & 15 \\
\hline & - & - & - & - & - & - & B & M & 2 \\
\hline & - & - & - & - & - & - & C & $\mathrm{F}$ & 5 \\
\hline & - & - & - & $\mathrm{C}$ & M & 10 & - & - & - \\
\hline Total interviews & 10 & & & 13 & & & 12 & & \\
\hline \multicolumn{10}{|c|}{ Focus group participants } \\
\hline \multirow[t]{4}{*}{ Nurses } & $3 \mathrm{~B}$ & $\mathrm{~F}$ & $5,9 \& 20$ & $3 \mathrm{~B}$ & $\mathrm{~F}$ & $3,8,16$ & $2 B$ & $\mathrm{~F}$ & $7 \& 11$ \\
\hline & $2 \mathrm{~B}$ & $M$ & $6 \& 10$ & $2 \mathrm{~B}$ & $\mathrm{M}$ & $9 \& 20$ & $2 \mathrm{C}$ & $\mathrm{F}$ & $15 \& 23$ \\
\hline & $2 \mathrm{C}$ & $\mathrm{F}$ & $7 \& 10$ & $3 \mathrm{~W}$ & $\mathrm{~F}$ & $7,9,11$ & $1 \mathrm{C}$ & M & \\
\hline & & & & $2 \mathrm{C}$ & $\mathrm{F}$ & $11 \& 13$ & $2 \mathrm{~W}$ & $\mathrm{~F}$ & $15 \& 21$ \\
\hline \multirow{3}{*}{$\begin{array}{l}\text { Allied healthcare } \\
\text { professionals }\end{array}$} & $2 \mathrm{~B}$ & $\mathrm{~F}$ & $15 \& 10$ & $2 \mathrm{~B}$ & M & $12 \& 13$ & $2 \mathrm{~B}$ & $\mathrm{M}$ & $7 \& 8$ \\
\hline & $2 W$ & $\mathrm{~F}$ & $15 \& 3$ & $2 W$ & $\mathrm{~F}$ & $8 \& 18$ & 11 & Ms & 11 \\
\hline & $2 \mathrm{C}$ & M & $10 \& 4$ & $3 \mathrm{C}$ & $\mathrm{F}$ & $3,8,11$ & $3 W$ & $\mathrm{~F}$ & $7,9,12$ \\
\hline \multirow{3}{*}{$\begin{array}{l}\text { General and } \\
\text { administration }\end{array}$} & $2 \mathrm{~B}$ & $\mathrm{M}$ & $35 \& 10$ & 3B & $\mathrm{F}$ & $7,9,16$ & $2 \mathrm{~B}$ & $\mathrm{~F}$ & $11 \& 15$ \\
\hline & $3 \mathrm{~B}$ & $\mathrm{~F}$ & $10,9 \& 7$ & $3 W$ & M & $7.8,20$ & $2 C$ & M & $12 \& 14$ \\
\hline & 11 & $\mathrm{~F}$ & 10 & $2 \mathrm{C}$ & M & $11 \& 17$ & $2 \mathrm{C}$ & $\mathrm{F}$ & $8 \& 18$ \\
\hline \multirow[t]{5}{*}{ Shop stewards } & $2 \mathrm{~B}$ & M & $7 \& 3$ & 3B & $\mathrm{F}$ & $1,10,15$ & $2 \mathrm{~B}$ & $\mathrm{~F}$ & $3 \& 15$ \\
\hline & 2 B & $\mathrm{F}$ & 1 & $2 B$ & Ms & $10 \& 13$ & $1 \mathrm{~B}$ & $\mathrm{M}$ & \\
\hline & $1 \mathrm{~W}$ & $\mathrm{~F}$ & 1 & $2 \mathrm{C}$ & M & $2 \& 5$ & $2 \mathrm{C}$ & $\mathrm{F}$ & $5 \& 8$ \\
\hline & $1 \mathrm{C}$ & $M$ & 4 & $1 \mathrm{~W}$ & $\mathrm{M}$ & 1 & $1 \mathrm{C}$ & $M$ & 2 \\
\hline & & & & & & & $1 \mathrm{~W}$ & $M$ & 7 \\
\hline
\end{tabular}

B, black; C, coloured; F, female; I, Indian; M, male; W, white.

they did not have permission to participate from their section manager despite several attempts to explain the purpose of the study. However, other groups of staff at a similar level (porters and mortuary attendants) did participate, and shop stewards, who represent a wide range of staff, were well represented in the study.

\section{Public and patient involvement}

No patients or members of the public were involved in the research design, analysis nor dissemination of the findings; however, hospital managers contributed to the research focus in the planning stages.

\section{FINDINGS}

\section{Implementation of austerity}

In response to austerity, the provincial department of health centralised all financial decision-making, introducing a provincial cost containment committee (PCCC) that reviewed every expenditure decision. While this committee enabled finance officials to control expenditure, clinical staff regarded it as a barrier to service delivery: 'To buy just a simple thing like electrodes which only costs (USD 60) we have to go through many steps. We have to sit as an Institutional (hospital) Costs Containment Committee on Monday, and then send our request to the District Costs Containment Committee that sits on Tuesday, and then on Wednesday sent it to the Provincial Costs Containment Committee. We then wait for their approval or disapproval. This has increased the turn-around time' (Senior Manager Hosp. A).

The lack of medical supplies delayed the provision of care: 'We don't have a haemoglobin (HB) monitor. We take blood, send it to another hospital, and wait until the following day to see if the patient needs transfusion or 
not' (Middle Manager Hosp. A). A nurse described her frustration with the lack of basic equipment: 'There is no mouth gauge, no scissors, there is only one stitch holder and we need two stitch holders. The sucking machine is not working, and the urinary cap is too big for the patients' (FGD: Professional Nurse Hosp. B).

Recruitment processes were prolonged, due to the same PCCG process, 'by the time we get approval, the selected applicants have accepted appointments elsewhere' (Senior Manager Hosp. C). The staff complement had been reduced: 'We had more than 200 staff, but now we have 180' (Junior employee Hosp. A). This led to a reduced service: 'We have 227 inpatients and more than 600 outpatients at the clinics, but we only have three doctors. They are supposed to go and monitor outpatients, but we have stopped those services in other areas' (Senior Manager Hosp. A).

\section{Leadership style, communication and stakeholder relations}

In Hospital B, there was better management, leadership and communication than in Hospital A and $\mathrm{C}$ with cohesion and teamwork among members of the top management. The management (CEO and the Director Human Resources) had been recently appointed in 2016 and had introduced more democratic management and open communication: 'We communicate with all the stakeholders regularly. All of them know what is within our control in the hospital and what issue are out of our control' (Senior Manager Hosp. B). A shop steward described the relationship with management: 'The CEO consults and involves unions in planning and when things do not go as planned, CEO comes to explain; CEO knows how to work with unions' (FGD: Shop steward Hosp. B).

A junior employee highlighted how this communication increased cohesion: 'If you have something that does not sit well with you, you can easily say it without fear of what will happen to you, so that it can be sorted out immediately; we are like one family, and even if someone is facing a disciplinary action, our managers don't abandon us, they support and defend us during that process' (FGD: Nursing Assistant Hosp. B).

In both Hospitals $\mathrm{A}$ and $\mathrm{C}$, poor communication led to conflict. In Hospital A, the lack of communication that applications for new staff had been rejected led to animosity between departments: 'It's a lie. Human Resources Management staff are not doing their job, yet they expected us to deliver and meet our targets; how?' (Senior Manager Hosp. A). A lack of information about an outbreak of Klebsiella led non-clinical staff to believe that management and clinical staff were intentionally exposing them to infection, when they did not inform staff about outbreak and took precautionary measures to protect themselves.

In Hospital C, shortage of staff led to a lack of teamwork: 'The doctors are refusing to do the calls of a doctor who has resigned. They said I must do them myself, because I am the one who have failed to hire a replacement' (Senior Manager Hosp. C). Other senior managers did nt attend meetings, reducing communication: 'My input is not valued in meetings and decisions are taken on our behalf, so I have decided it is better to assist my staff in providing front line services' (Senior Manager Hosp. C). Poor communication and a lack of understanding led one manager to believe that his posts were intentionally not filled and that payment of monies due to him were blocked by another manager. The result was a physical fight between the two managers.

Union-management relations were strained in Hospitals A and C. In Hospital C, the relations between labour and the CEO are poor: We need to work on that, because sometimes even meetings are not held as per the schedule' (Senior Manager Hosp. C). In Hospital A, senior management did not seem to recognise the importance of the union. The unions had decided not to engage with the CEO anymore.

\section{Strategies in response to austerity Hospital A}

Absorptive strategies were the most common in Hospital A (table 2), with staff performing multiple roles. Client information clerks were used in the procurement department, porters in mortuary, laundry staff in stores department. Nurses had to act as cleaners, kitchen staff and porters and mortuary staff at night. Nurses were expected to work above their professional scope of practice: 'Junior nurses manage wards, administer treatment, because they fear being reprimanded and charged for insubordination' (Senior Manager Hosp. A).

Some of the staff refused (such as mortuary staff acting as porters), if they considered the task to below their pay grade. Others responded by abusing their leave; a senior manager remarked on the increase in absenteeism and sick leave. One staff member admitted: 'I just go to the doctor and book myself off so that I can rest' (FGD: General Assistants Hosp. A)

As a consequence, nurses were doing less nursing work, presumably reducing the quality of care. Often department or ward managers often had to do the job themselves; attempts at disciplinary proceedings against the staff had failed because extra duties were not in their employment contracts, and some junior nurses refused to work beyond their scope because management did not support them when disciplinary actions were taken against them, for mistakes made.

At times staff used their own resources to fill in the gaps in hospital supplies, purchasing paper for the printer, or food for the patients: 'I buy food for the patients out of my pocket, and sometimes beg staff to contribute something so that we can make a decent meal for the patients' (Middle Manager Hosp. A). Although staff used their own resources, they were angry with their managers, for their apparent inability to manage and plan properly.

We found three examples of adaptive strategies in Hospital A. The hospital managed to revive its Ill Health Committee and ensured that staff on long incapacity leave, either came back to work or resigned. Managers 
Table 2 Management strategies and employee response to challenges in the face of austerity

\begin{tabular}{|c|c|c|c|c|}
\hline & State of management & Transformative & Adaptive & Absorptive \\
\hline Hospital A & $\begin{array}{l}\text { History of poor } \\
\text { management, } \\
\text { communication and } \\
\text { mistrust among } \\
\text { stakeholders. } \\
\text { Break down in } \\
\text { management-union } \\
\text { relations. } \\
\text { New management with } \\
\text { autocratic management } \\
\text { and leadership style. }\end{array}$ & $\begin{array}{l}\text { Pharmacist joined } \\
\text { the outreach team } \\
\text { when three contract } \\
\text { workers contracts were } \\
\text { terminated to assess and } \\
\text { monitored treatment use } \\
\text { and adherence at clinics. }\end{array}$ & $\begin{array}{l}\text { Non-governmental } \\
\text { partners asked to buy } \\
\text { items. } \\
\text { Revived III Health } \\
\text { Committee. } \\
\text { Borrowed supplies from } \\
\text { other hospitals. }\end{array}$ & $\begin{array}{l}\text { Clerks, laundry } \\
\text { worker, porters did } \\
\text { other work. } \\
\text { Nurses used as } \\
\text { cleaners, kitchen } \\
\text { staff, porters } \\
\text { and mortuary } \\
\text { attendants. } \\
\text { Junior nurses } \\
\text { manage wards } \\
\text { and administer } \\
\text { medication. } \\
\text { Borrow food and } \\
\text { drugs from other } \\
\text { hospitals. } \\
\text { Workers donated } \\
\text { money to buy food } \\
\text { for the patients. } \\
\text { Supervisor used } \\
\text { their money to } \\
\text { buy paper to print } \\
\text { documents. }\end{array}$ \\
\hline Hospital B & $\begin{array}{l}\text { New management had } \\
\text { democratic leadership } \\
\text { style. } \\
\text { Better communication } \\
\text { and trust among } \\
\text { stakeholders. } \\
\text { Teamwork and cohesion } \\
\text { among managers. }\end{array}$ & $\begin{array}{l}\text { In-service training for } \\
\text { management and shop } \\
\text { stewards continued. } \\
\text { Staff rotation. } \\
\text { Team discussion on } \\
\text { how to respond to staff } \\
\text { shortage. } \\
\text { Finance and HR } \\
\text { managers established of } \\
\text { bilateral forum. }\end{array}$ & $\begin{array}{l}\text { Used interns in finance } \\
\text { and supply chain. } \\
\text { Outsourced all services } \\
\text { that required highly } \\
\text { skilled artisan. } \\
\text { Used funds from } \\
\text { Hospital Board to buy } \\
\text { small items. }\end{array}$ & $\begin{array}{l}\text { Some staff worked } \\
\text { extra hours, late } \\
\text { and on weekends. } \\
\text { Staff paid overtime, } \\
\text { sometimes late. } \\
\text { Nurses used as } \\
\text { cleaners, clerks } \\
\text { and porters. } \\
\text { Junior nurses } \\
\text { administered } \\
\text { medication. }\end{array}$ \\
\hline
\end{tabular}

would borrow supplies from other hospitals while waiting for approval from head office: 'when our orders for food or medications come in, we give back whatever we had borrowed. It is not easy when it comes to this red tape' (Senior Manager Hosp. A). Management occasionally obtained assistance (such as electrolytes and haemoglobin metres) from non-governmental organisations.
We found one example of a transformative strategy in Hospital A. In response to the loss of staff, the hospital pharmacist was asked to join the outreach team to check whether patients collected their medication, which reduced the quantity of pills expiring without being used. As a result, limited outreach services continued in 
one subdistrict, with quicker identification of treatment defaulters, and improved treatment adherence.

\section{Hospital B}

Hospital B made use of several transformative strategies (table 2). First, in response to the cuts in the external training budget and the need to improve unions and management relations, management conducted in-service training on conflict management, labour relation issues, disciplinary proceedings and public service code of conduct and ethics, which both management and unions attended. This improved understanding of labour issues and has brought unions and management closer. A participant explained how this played out in day-to-day issues: 'The unit manager asked for our opinions on how best to resolve the issues. We felt important, as we were part of the solution and became willing participants. It is different when you are forced to do things by your superiors' (FGD: Professional Nurses Hosp. B).

Second, staff were rotated between different sections of the labour ward and inexperienced staff were paired with experienced staff, to facilitate on the job training. This allowed staff to gain skills and be flexible so that managers can use them in all sections of the labour ward.

Thirdly, a regular bilateral forum was created to allow finance and human resources managers to resolve challenges: 'It is not a formal structure, but something that we initiated, and its success depends on our willingness to cooperate with each other to resolve issues' (Senior Manager Hosp. B). HR and finance staff were able to learn more about how their individual tasks fitted into broader processes, and how challenges arose. Salary queries were resolved more quickly and accurately, and employee satisfaction increased.

The management in Hospital B also made use of three adaptive strategies. They deployed temporary interns in the finance and supply chain departments: "we are able to process orders on time so that goods and services can be delivered and payments made within the stipulated 21 days' (FGD: Shop stewards Hosp. B). Particular tasks in the engineering and maintenance sections were outsourced. This reduced the disruptions to services due to faculty equipment and machinery. Management used its monthly allocation of R7000 from the hospital board to buy items that were needed urgently in the hospital such as haemoglobin metres and glucose tests strips. (The hospital's Committee on Ill-Health and Incapacity had continued to function.)

Three absorptive strategies were used. As in other hospitals, staff were asked to do other duties: 'We request nurses to be porters, mortuary attendants, general assistants and clerks when needed' (Senior Manager Hosp. B). Nurses were also asked to function above their scope of clinical practice but were happy and willing to assist. 'Everyone knows that the patients is our priority and therefore we have to work together to achieve our goals as the hospital' (FGD: Professional Nurses Hosp. B). In the transport section, the number of drivers had been reduced from 12 to 3 , and staff with driver's licences drove themselves to their destinations. Management also obtained permission for staff to work overtime, although overtime payments were often late.

\section{Hospital C}

Hospital C used one transformative strategy (table 2), staff rotation in the labour ward: 'all staff here are rotating within these units, and everyone knows everything that is happening here' (Senior Managers Hosp. C), minimising disruptions due to gaps in staffing.

Hospital C used three adaptive strategies. As in Hospital A, they managed to reduce the number of staff on long incapacity leave by re-establishing the internal committee on incapacity. To alleviate shortages of general workers, the management attempted to obtain the assistance of the Government's Extended Public Works Programme to provide 40 workers as an interim solution. However, poor communication and mistrust resulted in the unions rejecting the management's initiative, and staff continued to experience pressure and high workload. As in other hospitals, Hospital C borrowed food and medication from other hospitals.

Management in hospital $\mathrm{C}$ made extensive use of absorptive strategies, similar to Hospital A. Junior nurses were expected to administer treatment, clean the wards, fetch the food trolley and serve food to the patients. This generated resistance: 'We do what we are asked to do, even though we are not happy about it, as we are afraid of being charged for not following law full orders from the superiors' (FGD: Nurses Hosp. C). It also led to conflict between operations and nursing managers as the nursing manager felt it is not her responsibility to assist the cleaning department as they have their own challenges which cleaners cannot assist with. If staff had skills beyond their formal job, they were used in different roles; general assistants and cleaners acted as welders, electricians and housekeepers. However, without any additional compensation for several years, these staff felt demotivated and abused.

\section{DISCUSSION}

In this study, we sought to examine the response of staff and managers in three public hospitals to austerity, and the effect on how the hospitals functioned. Austerity and the introduction of a PCCC led to a reduction in the number of staff, shortages of equipment, reduced staff benefits and delayed procurement and recruitment processes. Managers in Hospital B were able to steer the organisation, manage actors and facilitate the development of resilience capacity. They maintained training on labour relations for staff and managers, they jointly planned how to cope with reduced staff, and initiated a new forum for HR and finance staff; these transformative strategies improved the way actors engaged, enabling them to resolve problems. The good communication ensured that staff understood what was within the 
control of the hospital and what was not. In Hospitals A and $\mathrm{C}$, management failed to work together and build resilience capacity, and tensions surfaced and worsened organisational performance. Hospital A did not use any transformative strategies and mostly relied on absorptive ones, asking staff to do more with less. The result was resistance, and greater use of sick leave; some staff gave their own money to help feed patients but were angry at management for putting them in this difficult position. The leadership in Hospital $\mathrm{C}$ did not manage actors well either; the strategy of getting help from the expanded public works programme was rejected, managers did not attend meetings as they felt their contributions were not needed. The poor communication meant that the managers and staff did not understand what was within the control of the hospital and what was not; a misunderstanding led to a physical fight between managers.

Managers who encourage staff to voice their views are able to tap into their ideas, knowledge and experiences, allowing solutions to be generated at different levels of the organisation, often for problems that leadership do not know about. ${ }^{16}$ Empowering, and acknowledging staff's contribution, as achieved in Hospital B, improves staff attitudes, loyalty, commitment, co-operation, performance and leads to the generation of 'local' solutions. In contrast, employee silence reduces managerial access to important information, undermines organisational decision-making, damages employee trust, morale and leads to dissatisfaction, low commitment, stress and disengagement, ${ }^{16-19}$ as we found in Hospitals A and C.

With austerity, and staff being asked to do more with less in every organisation, management has to move away from an autocratic approach and hostile union-management relations, to a co-operative partnership where new ways of working can be developed. ${ }^{20-24}$ All three hospitals asked nurses to work outside their scope of practice. Staff in most organisations are keen to learn on the job and gain extra skills, and implementation of a scope of work in practice will always vary to some extent in different contexts. In our study, where managers were supportive of staff (Hospital B), and so were likely to defend staff if there was a disciplinary hearing, nurses were willing to do the extra work; where managers were not supportive of staff (Hospitals A and $\mathrm{C}$ ) nurses voiced their objections and resisted doing the additional work. ${ }^{2} 61325$

Our findings highlight how capacity to manage actors well, actor networks and interconnectedness promoted resilience ${ }^{67}$ For example, the forum established between human resources and finance departments, training on labour relations, meetings to plan how to respond to shortage of staff and rotating staff between sections of a ward. These strategies were transformative because they improved the way the actors engaged with each other, they allowed staff to develop 'local' solutions; in essence, they are examples of distributed leadership. ${ }^{26-29}$

The joint union and management training on labour relations (Hospital B) allowed for explicit discussion of tension generated as a result of austerity; such discussions were not taking place in Hospital A or C, as management was autocratic and lacked the capacity to manage the different actors well. ${ }^{30}$ In contrast, absorptive strategies put strain on existing actor interconnectedness, by putting pressure on staff to expand their scope of work and work harder.

It is important to note that Hospital B managed to achieve better actor management and actor interconnectedness, despite its greater size (with over 2000 staff) than the two small hospitals (with 200 and 600 staff).

\section{Strengths and limitations}

Our study extends existing research on austerity and resilience by looking at management strategies, employee responses and the effect on hospital functioning in a middle-income country setting. A major strength of our study is the variety of employee and managers roles among the participants. Although the study hospitals are typical of many South African public hospitals, the findings cannot be generalised to all public hospitals, especially as the institutions were located in urban areas, and therefore are more likely to have greater resources than those in rural areas. The use of convenience sampling may have prevented some staff participating, as those busy working due to staff shortages or on leave during the study, may have been excluded. The participation of shop stewards who represent diverse employee groups provided a range of views even though three groups of staff from one of the three hospitals did not participate in the study.

\section{CONCLUSION}

In a period of austerity, there is increasing pressure and expectation to 'do more with less', while improving access to quality healthcare in line with international calls for universal coverage. Managers need the capacity to manage different actors, networks and institutions in order to deal or generate organisational resilience. In times of austerity, hospital managers who promote democratic or participatory leadership and management, open communication, teamwork and trust among all stakeholders will lead better functioning organisations. A special focus should be placed on developing such practices to enable organisations to respond to austerity in a way that develops the resilience of health systems organisations.

Contributors Authors have equally contributed to this manuscript.

Funding The authors have not declared a specific grant for this research from any funding agency in the public, commercial or not-for-profit sectors.

Competing interests None declared.

Patient consent for publication Informed consent was obtained from all respondents.

Ethics approval The University of the Witwatersrand's Human Research Ethical Committee (Medical) and the Provincial Department of Health, Health Research Committee, granted the ethical clearance for this study (clearance certificates number M181143 and 201903-008).

Provenance and peer review Not commissioned; externally peer reviewed. 
Data availability statement Data are available upon request. The data collected and or analysed during the study related to this paper are not publicly available due to the conditions of the ethics approval, but they are available from the corresponding author upon consideration of the request.

Supplemental material This content has been supplied by the author(s). It has not been vetted by BMJ Publishing Group Limited (BMJ) and may not have been peer-reviewed. Any opinions or recommendations discussed are solely those of the author(s) and are not endorsed by BMJ. BMJ disclaims all liability and responsibility arising from any reliance placed on the content. Where the content includes any translated material, BMJ does not warrant the accuracy and reliability of the translations (including but not limited to local regulations, clinical guidelines, terminology, drug names and drug dosages), and is not responsible for any error and/or omissions arising from translation and adaptation or otherwise.

Open access This is an open access article distributed in accordance with the Creative Commons Attribution Non Commercial (CC BY-NC 4.0) license, which permits others to distribute, remix, adapt, build upon this work non-commercially, and license their derivative works on different terms, provided the original work is properly cited, appropriate credit is given, any changes made indicated, and the use is non-commercial. See: http://creativecommons.org/licenses/by-nc/4.0/.

\section{ORCID iDs}

Thanduxolo Fana http://orcid.org/0000-0003-4439-2555

Jane Goudge http://orcid.org/0000-0001-6555-7510

\section{REFERENCES}

1 Maley JF. Preserving employee capabilities in economic turbulence. Human Resource Management Journal 2019;29:147-61.

2 Massuda A, Hone T, Leles FAG, et al. The Brazilian health system at crossroads: progress, crisis and resilience. BMJ Glob Health 2018;3:e000829.

3 Overmans J. F. A. (Tom), Noordegraaf M. Managing austerity: rhetorical and real responses to fiscal stress in local government. Public Money \& Management 2014;34:99-106.

4 Kerasidou A, Kingori P, Legido-Quigley H. "You have to keep fighting": maintaining healthcare services and professionalism on the frontline of austerity in Greece. Int J Equity Health 2016;15:118.

5 Blecher M, Mansvelder A, Gaarekwe O. Health spending at a time of low economic growth and fiscal constraint. South African Health Review 2017;1:25-39.

6 Kagwanja N, Waithaka D, Nzinga J, et al. Shocks, stress and everyday health system resilience: experiences from the Kenyan coast. Health Policy Plan 2020;35:522-35.

7 Blanchet K, Nam SL, Ramalingam B, et al. Governance and capacity to manage resilience of health systems: towards a new conceptual framework. Int J Health Policy Manag 2017;6:431-5.

8 Malelelo-Ndou H, Ramathuba DU, Netshisaulu KG. Challenges experienced by health care professionals working in resource-poor intensive care settings in the Limpopo Province of South Africa. Curationis 2019;42:1-8.

9 Maphumulo WT, Bhengu BR. Challenges of quality improvement in the healthcare of South Africa post-apartheid: a critical review. Curationis 2019;42:1-9.

10 Govender S, Gerwel Proches CN, Kader A. Examining leadership as a strategy to enhance health care service delivery in regional hospitals in South Africa. J Multidiscip Healthc 2018;11:157-66.
11 Pillay P, Mantzaris E. Corruption in the health sector in South Africa and India: some considerations and reflections. African Journal of Public Affairs 2017;9:48-62.

12 Taslimi MS, Azimi A, Nazari M. Resilience to economic sanctions; case study: Hospital equipment cluster of Tehran (HECT). Int J Disaster Resil Built Environ 2020;12:13-28.

13 Nyikuri M, Tsofa B, Barasa E, et al. Crises and resilience at the Frontline-Public health facility managers under devolution in a SubCounty on the Kenyan coast. PLoS One 2015;10:e0144768.

14 Gilson L, Barasa E, Nxumalo N, et al. Everyday resilience in district health systems: emerging insights from the front lines in Kenya and South Africa. BMJ Glob Health 2017;2:e000224.

15 Ohemeng FLK, Obuobisa Darko T, Amoako-Asiedu E. Bureaucratic leadership, trust building, and employee engagement in the public sector in Ghana. International Journal of Public Leadership 2019;16:17-40.

16 Adăscăliței D, Muntean A. Trade Union strategies in the age of austerity: the Romanian public sector in comparative perspective. European Journal of Industrial Relations 2019;25:113-28.

17 Bassey AOet al. The impact of inter-union conflicts on industrial harmony: the case of tertiary health institutions in cross river state, Nigeria. Geografia-Malaysian Journal of Society and Space 2017;8.

18 Brinsfield CT, Edwards MS. Employee voice and silence in organizational behavior. In: Handbook of research on employee voice. Edward Elgar Publishing, 2020.

19 Prouska R, Psychogios A. Do not say a word! Conceptualizing employee silence in a long-term crisis context. The International Journal of Human Resource Management 2018;29:885-914.

20 Cekiso M, Maqhubela V. Exploring working relationships between Union representatives and school management teams in the rural public schools of South Africa: implications for school management. International Journal of Educational Sciences 2015;8:319-26.

21 Geary J. Economic crisis, austerity and trade Union responses: the Irish case in comparative perspective. European Journal of Industrial Relations 2016;22:131-47.

22 McNamara T, Spyridakis M. Introduction-trade unions in times of austerity and development. Springer, 2020.

23 Mogotsi M. The role of trade unions in enhancing work engagement, work commitment, job satisfaction and job performance in a Government Institution. North-West University (South Africa), 2019

24 Msila V. Teacher unionism and school management: a study of (eastern Cape) schools in South Africa. Educational Management Administration \& Leadership 2014;42:259-74.

25 Barasa Eet al. Recentralisation within decentralisation? Improving the functioning of Kenyan hospitals through increased Hospital autonomy. Kilifi, Kenya, 2016.

26 Currie G, Spyridonidis D. Sharing leadership for diffusion of innovation in professionalized settings. Human Relations 2019;72:1209-33.

27 Günzel-Jensen F, Jain AK, Kjeldsen AM. Distributed leadership in health care: the role of formal leadership styles and organizational efficacy. Leadership 2018;14:110-33.

28 Nzinga J, McGivern G, English M. Examining clinical leadership in Kenyan public hospitals through the distributed leadership lens. Health Policy Plan 2018;33:ii27-34.

29 Pearce CL, Wood BG, Wassenaar CL. The future of leadership in public universities: is shared leadership the answer? Public Adm Rev 2018;78:640-4.

30 Topp SM. Power and politics: the case for linking resilience to health system governance. BMJ Glob Health 2020;5:e002891. 